\title{
Recent developments of 3D models of the tumor microenvironment for cutaneous melanoma: Bridging the gap between the bench and the bedside?
}

\author{
Johanna Maria Hölken and Nicole Elisabeth Teusch* \\ Department of Biomedical Sciences, Institute for Health Research and Education, University of Osnabrück, Germany
}

\begin{abstract}
In cancer drug discovery, 3D approaches have been implemented over the last years to model the complex tumor architecture and the heterogenous components of the tumor microenvironment. Cutaneous melanoma represents a cancer of substantial unmet need with steadily growing incidence. Bioengineering techniques are increasingly applied to design melanoma-specific models. Here, we summarize how extracellular and cellular elements of the melanoma tumor microenvironment have been studied in 3D cell culture models. We review the benefits of such models and address their limitations and future perspectives for the development of novel therapeutic strategies.
\end{abstract}

\section{Introduction}

According to the world health organization (WHO) cancer is the second leading cause of death worldwide [1]. Although comprising $<5 \%$ of all skin cancer cases, melanoma represents the most aggressive subtype accounting for $>80 \%$ of skin-cancer related deaths and the numbers of cases are rising rapidly [2]. Accordingly, mortality and morbidity is relatively high with approximately 50.000 deaths annually worldwide, especially due to the occurrence of metastases [3]. After lung and breast cancer, melanoma is the third most common type of cancer likely to metastasize predominantly to the brain [4-6]. In fact, an estimated $10-40 \%$ of melanoma patients will develop brain metastases [7]. Thus, prognosis of patients with melanoma brain metastases (MBM) is poor, with an expected overall survival (OS) of only 4 months, [8-10].

In melanoma, the mitogen-activated protein kinase (MAPK) pathway is ubiquitously activated due to point mutations in the v-Raf murine sarcoma viral oncogene homolog B (BRAF) (35\%-50\% of melanomas) and in the Neuroblastoma RAS viral oncogene homolog (NRAS) (10\%-25\%). Efforts to target this pathway resulted in the approval of the BRAF inhibitors vemurafenib and dabrafenib, the mitogen-activated protein kinase (MEK) inhibitor trametinib, and the combination treatment of dabrafenib + trametinib [11]. Conventional therapy for MBM consists of whole brain radiation therapy for multiple metastases and radiosurgery or radiotherapy for limited numbers of metastases [12]. Despite the invention of new systemic drugs, such as immunotherapy with checkpoint inhibitors like anticytotoxic T-lymphocyte-associated protein 4 (ipilimumab) [13,14], anti-programmed cell death protein 1 (anti-PD1) (nivolumab and pembrolizumab) $[15,16]$ or a combination [17], and targeted therapy (BRAF, MEK inhibitors) [18-21], outcomes remain poor and new efficacious therapies are urgently needed.

However, to date, the success rate of novel antitumor drugs transitioning in the clinic to phase 3 is in general relatively low [22-24]. Since clinical trials are, amongst others, initiated based on evidence of efficacy in preclinical cell-based and mostly rodent models, clearly these models need to become more predictive in future drug development. The cellular heterogeneity of the tumor and its surrounding microenvironment combined with mechanical forces due to the threedimensional (3D) architecture as well as hypoxia and gradients of nutrients may influence the efficacy of potential therapeutics, making it critical to consider 3D models when examining novel anti-cancer drug candidates.

This review aimed to describe the current concepts of $3 \mathrm{D}$ in vitro cutaneous melanoma models, compare the key characteristics of these $3 \mathrm{D}$ models versus two-dimensional (2D) models, and discuss the potential as well as the challenges of current $3 \mathrm{D}$ melanoma models for future drug discovery efforts.

\section{Main part}

The tumor microenvironment: A key player in melanoma carcinogenesis

The oversimplification of human tumors using $2 \mathrm{D}$ in vitro models explains why these "monolayer" models fail to capture the extent and nature of cell-cell and cell-extracellular matrix (ECM) interactions as well as nutrients and oxygen gradients that can occur due to the $3 \mathrm{D}$ configuration of human tumors [25]. Over the past decades, cancer research has been initially focused on cancer cells and on understanding their transformation into tumor cells. However, recently it has become clear that the tumor microenvironment (TME) with its cellular and molecular heterogeneity has a major impact on tumor progression as well as metastasis formation and spreading into distant tissues.

${ }^{*}$ Correspondence to: Nicole Elisabeth Teusch, Department of Biomedical Sciences, Institute for Health Research and Education, University of Osnabrück, Germany, Email: nicole.teusch@uni-osnabrueck.de

Received: April 21, 2020; Accepted: May 02, 2020; Published: May 07, 2020 

bedside?

Melanoma results originally from malignant transformation of melanocytes, which are naturally occurring pigmented cells in the epidermis to protect mitotically active keratinocytes against damage caused by UV-light irradiation. The melanocytes originate in the neural crest and consequently migrate to the epidermis. Melanocyte migration is guided by an intercellular crosstalk with i.e. keratinocytes [26]. Keratinocytes are also involved in melanoma progression [27] and their presence is essential to study cellular responses to drug candidates in a complete tumor microenvironment. Hence, the microenvironment of melanoma is formed not only by malignant cells but also by complex interactions with non-cancerous stromal cells, such as keratinocytes, cancer associated fibroblasts (CAFs), infiltrating immune cells, blood/ lymphatic endothelial cells as well as biochemical components of the extracellular matrix, that all participate in melanoma formation and growth [28].

In addition to the highly heterogeneous cancer cell populations, the complex stromal tissue acts as a repository for various growth factors and cytokines that can greatly affect tumor growth and drug response [29-31]. Various growth factors secreted by CAFs also enhance an epithelial-mesenchymal transition (EMT) and the therapeutic resistance of cancer [32]. CAFs from melanoma influence also keratinocytes and, among others, induce expression of vimentin, a cytoskeletal protein involved in EMT, which is only weakly expressed in normal human keratinocytes [33]. Furthermore, 3D co-culture experiments showed that CAFs promote migration and invasiveness of melanoma cells and such migration is for instance dependent on interleukin-6 (IL-6) and interleukin-8 (IL-8) secretion [34]. Angiogenesis and metastases may be accompanied by secretion of IL- 8 from tumor stroma confirming its prognostic significance as a circulating biomarker of melanoma [35]. Accordingly, serum levels of IL-8 correlate with tumor stage [36]. Similar to IL-8, production of hepatocyte growth factor (HGF) by stromal cells enhances melanoma invasiveness and elevated HGF levels in melanoma are accompanied by chemotherapy resistance [37]. Noteworthy, a variety of additional extracellular components including enzymes, such as matrix remodeling proteases, extracellular vesicles (EVs), such as exosomes [38], as well as EV transferred cargo including miRNAs [39], and nutrient and oxygen gradients synergistically participate in control of melanoma progression.

Hence, non-cancerous cells of the tumor microenvironment can significantly affect the efficacy of melanoma cells to therapeutic agents. For instance, in a vascularized 3D spheroid model melanoma cell proliferation after chronic treatment with vemurafenib was less pronounced in spheroid regions with fibroblasts, indicating an effect of the microenvironment on drug response [40]. Consequently, therapeutic manipulation of the tumor microenvironment has to be considered a highly promising approach which cannot be technologically addressed in classical 2D cell culture models.

\section{The immune response in melanoma: Two sides of a medal}

Improved understanding of the tumor microenvironment has resulted in innovative treatment approaches targeting the immune response, such as immunotherapy with checkpoint inhibitors like anticytotoxic T-lymphocyte-associated protein 4 (ipilimumab) $[13,14]$ or anti-programmed cell death protein 1 (anti-PD1) (nivolumab and pembrolizumab) $[15,16]$. Among the immune cells infiltrating melanoma, the T-lymphocytes play a central role in anti-cancer immunity and, the degree of T-cell accumulation within the tumor is an important predictor of response of patients to immunotherapy [41]. Some common tumor microenvironment characteristics in melanoma include the presence of tumor-associated macrophages of the M2type (M2 TAMs) and regulatory T-lymphocytes (Treg) as non-tumor cells, which represent targets for immunotherapy by contributing to the escape of melanoma cells from immune defence mechanisms $[42,43]$. Distinct chemokines produced by tumor infiltrating macrophages may help to recruit Tregs to the tumor and maintain an immunosuppressive tumor microenvironment in melanoma [43]. As both cell types have a prominent immunosuppressive action, they promote skin carcinogenesis $[44,45]$. Notably, tumor infiltration by such immunosuppressive cells relates to unfavorable prognosis.

In contrast, other immune cells present in the tumor stroma, such as natural killer (NK) cells, M1-type macrophages or dendritic cells, have been reported to induce a protective anti-tumor immune response $[46,47]$, underlying the ambiguous role of the immune response in melanoma. For instance, NK cells have an important role in innate and adaptive immunity through cytokine secretion and interaction with dendritic cells.

In conclusion, as immune cell components of malignant melanoma are essential for investigating novel treatment approaches, an integration into preclinical in vitro models appears mandatory.

\section{Recent development in human 3D melanoma models}

Like most cancer types, melanoma has been initially studied in vitro in conventional 2D cell culture models. Indeed, 2D cell culture has its benefits in low costs and as a fast method for high throughput drug screening with high reproducibility $[48,49]$. However, while 2D monolayer cell cultures have unlimited access to nutrients, oxygen, metabolites and signal molecules, 3D models may come closer to the physiological situation in vivo [48-50], as already indicated. In addition, when compared $2 \mathrm{D}$ and $3 \mathrm{D}$ cancer models for the same tumor entity, differences in cell metabolism, proliferation, apoptosis-related genes, chemoresistance related genes, the amount of cancer stemness, and miRNA profiles have subsequently been noted including melanoma $[48,49,51]$.

In particular, for melanocytes and melanoma cells genetic alterations and loss of phenotype during 2D monoculture have been described. Already in 1987 it was observed that 2D culture conditions supporting the rapidly proliferation of human melanocytes, resulted in antigenic changes (expression of surface antigens as nerve growth factor receptor, proteoglycan, transferrin-related $\mathrm{M}, 120,000$ protein etc.), associated with malignant melanomas [52]. Furthermore, mutations in the $16 / C D K N 2$ tumor suppressor gene have been revealed in different melanoma cell lines during 2D culture, but not in primary lesions in situ [53,54]. In addition, despite chemotherapeutic drugs or radiation therapy demonstrate efficacy in $2 \mathrm{D}$ cultures, their activity may change significantly in vivo, partially affected by the TME $[55,56]$.

In order to consider the tumor microenvironment in preclinical drug discovery, genetically engineered mouse models (GEMM) of cancer, human xenotransplant mice, or 3D organ co-cultures have been implemented. However, less than $8 \%$ of all results from animal models are reproducible in clinical cancer trials [57] and, notably, skin physiology and immunity of mice is significantly different from human skin. While melanocytes in mouse skin are mostly localized in hair follicles, determining the color of the fur, human melanocytes locate primarily at the basal layer of the epidermis, where they respond to UV-light by generating the pigment melanin and transferring it to the keratinocytes $[58,59]$. Thus, based on the significant differences 
Hölken JM (2020) Recent developments of 3D models of the tumor microenvironment for cutaneous melanoma: Bridging the gap between the bench and the bedside?

between mice and human skin anatomy and physiology, mouse models are limited to study melanoma progression in general and the specific role of tumor microenvironment in particular.

Hence, the research in implementing 3D models to study melanoma and its environment in three-dimensional conditions has been significantly developed. Recent advancements in 3D melanoma models are depicted in Figure 1 and chronologically listed with additional information in Table 1.

The very first 3D tumor spheroid model was generated in 1970/71 $[76,77]$ and one of the first melanoma 3D spheroids was described 3 years later in 1973 by Folkman and Hochberg [61] . The first 3D melanoma model was based on a murine melanoma cell line (B16). In 1981, a preliminary in vitro full-thickness skin model was developed using rat fibroblasts seeded in a collagen lattice and littered with endothelial cells [64]. Melanoma spheroids generated directly from human tumor material have been described in 1984 [65]. Finally, in 2000, several research groups developed different approaches for humanized 3D fullthickness melanoma models [66-68,78]. While most of them utilized human de-epidermised dermis (DED) (isolated from split thickness skin grafts or skin from skin banks) as dermal layer, seeding melanoma cells, keratinocytes and/ or fibroblasts on top [66,67,78], Meier et al. developed the first completely cell-based human 3D full-thickness melanoma model using fibroblasts and collagen to form a dermal basis, finally adding melanoma cells and keratinocytes on top [68]. One of the first completely cell-based human 3D full-thickness melanoma model with integrated endothelial cells and without DED as a dermal basis was developed in 2013 [70]. Furthermore, in 2013, Vörsmann et al. invented a human 3D full-thickness cell-based melanoma model based on integrated melanoma spheroids instead of single melanoma cells [56].

Noteworthy, to this date, fibroblast collagen I, the primary component of the ECM, derived from rat tails or bovines was

Table 1: Selected milestones in the development of 3D cutaneous melanoma models. Blue highlighted table rows are depicted in the timeline in figure 1. ECM stands for extra cellular matrix

\begin{tabular}{|c|c|c|c|c|}
\hline Year & Milestone & Cell Types & ECM/ scaffold & Reference \\
\hline 1967 & $\begin{array}{l}\text { Establishment of the first human melanoma cell lines } \\
\text { (monolayer) in cell culture }\end{array}$ & $\begin{array}{l}\text { Patient-derived melanoma cell lines ( } \mathrm{LeCa} 19.4, \mathrm{LeCa} \\
\text { 26.5, MeGo) }\end{array}$ & - & {$[60]$} \\
\hline 1973 & Development of the first 3D melanoma spheroid (murine cells) & Murine B-16 melanoma cells & Soft agar & {$[61]$} \\
\hline 1973 & $\begin{array}{l}\text { Establishment of the first human melanoma cell lines in } \\
\text { suspension cell culture }\end{array}$ & Patient-derived melanoma cell lines (A-375, A-875) & - & {$[62]$} \\
\hline 1975 & Establishment of human keratinocyte cell culture & $\begin{array}{c}\text { Primary human keratinocytes co-cultured with lethal } \\
\text { irradiated } 3 \mathrm{~T} 3 \text { cells }\end{array}$ & - & {$[63]$} \\
\hline 1981 & $\begin{array}{c}\begin{array}{c}\text { Development of the first in vitro full-thickness skin model (rat } \\
\text { cells) }\end{array}\end{array}$ & $\begin{array}{c}\text { Primary rat fibroblasts co-cultured with epidermal cells } \\
\text { (rat) }\end{array}$ & Collagen lattice & {$[64]$} \\
\hline 1984 & $\begin{array}{l}\text { Development of the first human melanoma spheroids (grown } \\
\text { directly from patient material) }\end{array}$ & Patient-derived melanoma cells & Agar coated flask & {$[65]$} \\
\hline 2000 & Development of a human 3D full-thickness melanoma model & $\begin{array}{c}\text { Primary human keratinocytes, fibroblasts, metastatic } \\
\text { melanoma cell line (HBL) }\end{array}$ & Natural ECM of DED & {$[66]$} \\
\hline 2000 & $\begin{array}{c}\text { Development of a human 3D full-thickness melanoma model } \\
\text { with melanoma cells from RGP, VGP or metastatic melanoma } \\
\text { cell lines to study early melanoma metastasis }\end{array}$ & $\begin{array}{c}\text { Primary human keratinocytes, melanoma cell lines from } \\
\text { RGP (PM-WK), VGP (RPM-EP), or metastatic cell lines } \\
\text { (MM-AN, MM-RU) } \\
\text { No fibroblasts }\end{array}$ & Natural ECM of DED & {$[67]$} \\
\hline 2000 & $\begin{array}{l}\text { Development of the first completely cell-based human 3D full- } \\
\text { thickness melanoma model }\end{array}$ & $\begin{array}{c}\text { Primary human keratinocytes, fibroblasts, melanoma cell } \\
\text { lines from RGP (WM35), VGP (WM793), metastatic } \\
\text { melanoma line (WM852) }\end{array}$ & Collagen & {$[68]$} \\
\hline 2005 & $\begin{array}{c}\text { Isolation of multipotent stem-cell populations from } \\
\text { subpopulation of spheroids of established melanoma cell lines }\end{array}$ & $\begin{array}{l}\text { Established human primary melanoma cell line (WM115) } \\
\text { and metastatic melanoma cell line (WM239A) }\end{array}$ & $\mathrm{n} / \mathrm{a}$ & {$[69]$} \\
\hline 2013 & $\begin{array}{l}\text { Development of a completely cell-based human 3D full- } \\
\text { thickness microvascularized melanoma model: Integration } \\
\text { of a metastatic melanoma cell line induced pro-angiogenic } \\
\text { effect on endothelial cells and lead to a more branched } \\
\text { microvascular network }\end{array}$ & $\begin{array}{c}\text { Primary human keratinocytes and fibroblasts, human } \\
\text { umbilical vein endothelial cells (HUVEC), primary } \\
\text { melanoma cell lines (A375, SK MEL 28), metastatic } \\
\text { melanoma cells (Malme3, RPMI7951) }\end{array}$ & Paper anchor & {$[70]$} \\
\hline 2013 & $\begin{array}{l}\text { Development of a completely cell-based human 3D full- } \\
\text { thickness skin melanoma spheroid model }\end{array}$ & $\begin{array}{l}\text { Primary human fibroblasts, keratinocytes and tumor } \\
\text { spheroids (451-LU cell line, MM). }\end{array}$ & Collagen I (rat tail) & {$[56]$} \\
\hline 2015 & $\begin{array}{l}\text { Development of a human 3D full-thickness melanoma } \\
\text { invasion model with human fibroblasts stimulated to produce } \\
\text { their own ECM constituents (collagen III, IV and VII) }\end{array}$ & $\begin{array}{c}\text { Primary human fibroblasts, keratinocytes, primary human } \\
\text { melanoma cell line (WM35) or metastatic melanoma cell } \\
\text { line (SK-MEL-28) }\end{array}$ & Alvetex scaffold & {$[71]$} \\
\hline 2016 & $\begin{array}{l}\text { Development of a wounded and inflamed human 3D } \\
\text { melanoma model to investigate the use of an anti- } \\
\text { inflammatory drugs on melanoma invasion }\end{array}$ & $\begin{array}{l}\text { Primary human fibroblasts, keratinocytes, metastatic } \\
\text { melanoma cell lines (HBL, A375-SM, C8161) }\end{array}$ & Natural ECM of DED & {$[72]$} \\
\hline 2017 & $\begin{array}{l}\text { Development of a human 3D melanoma model to study } \\
\text { melanoma invasion over time and invasion depth }\end{array}$ & $\begin{array}{c}\text { Primary human fibroblasts, keratinocytes and melanoma } \\
\text { cell line from early RGP (WM35) or metastatic melanoma } \\
\text { cells (SK-MEL-28) }\end{array}$ & Natural ECM of DED & {$[73]$} \\
\hline 2018 & $\begin{array}{l}\text { Development of the first 3D melanoma model with blood and } \\
\text { lymphatic capillaries }\end{array}$ & $\begin{array}{c}\text { Human fibroblasts, keratinocytes, human microvascular } \\
\text { endothelial cells (HMVEC (LEC \& BEC pos.)), melanoma } \\
\text { spheroids (A375, Malme } 3 \text { M, SK-MEL 28, RPMI 7951, } \\
\text { WM983A, or WM983B) }\end{array}$ & Paper anchor & {$[40]$} \\
\hline 2019 & $\begin{array}{l}\text { Construction of a 3D lymph node/melanoma immune- } \\
\text { enhanced organoid from the patient's own tumor (may allow } \\
\text { studies for personalized immunotherapy) }\end{array}$ & $\begin{array}{c}\text { Patient lymph node }+ \text { melanoma tissue was shredded and } \\
\text { digested to win the cells. All cells (unsorted) were seeded } \\
\text { into ECM- mimicking collagen-based hydrogel }\end{array}$ & $\begin{array}{l}\text { HA/collagen- based } \\
\text { hydrogel system }\end{array}$ & [74] \\
\hline 2019 & $\begin{array}{l}\text { Development of a human 3D immune enhanced melanoma } \\
\text { model to study young vs aged microenvironment in melanoma }\end{array}$ & $\begin{array}{l}\text { Human keratinocytes, young and aged fibroblasts, } \\
\text { melanoma cell lines (1205lu, WM3918), T-cells }\end{array}$ & Collagen & {$[75]$} \\
\hline
\end{tabular}



bedside?

1973: First 3D
melanoma spheroid
model (murine cells)

1984: First human melanoma spheroids (grown from patient material)
2013: Human 3D fullthickness microvascularized melanoma model
2018: First human 3D fullthickness melanoma spheroid model with blood and lymphatic capillaries

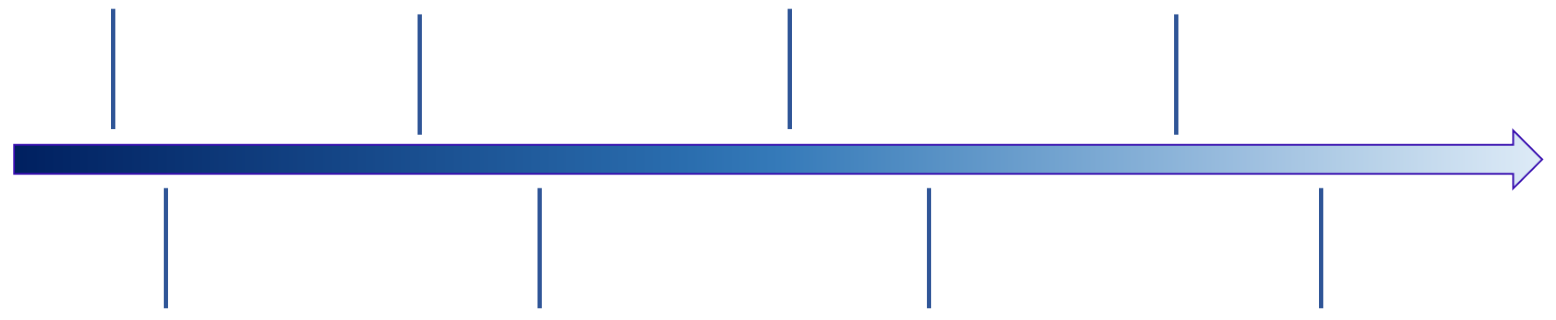

1975: Etablishment of human keratinocyte cell culture
2000: Different human 3D full-thickness melanoma models
2015: Human 3D fullthickness melanoma invasion model without animal collagen. Fibroblasts produce own ECM constituents
2019: Human 3D fullthickness immune enhanced melanoma model to study aging of the melanoma microenvironment

Figure 1: Timeline of selected milestones in the development of 3D cutaneous melanoma models. The details of selected milestones are listed in table 1

implemented in most cell-based models to form of the dermal layer. The first human 3D full-thickness melanoma model without animalbased collagen was described in 2013 by Gibot et al. [70] and in 2015 Hill et al. proved their model producing its own ECM constituents (collagen III, IV and VII) [71]. The first and so far only described cellbased human 3D full-thickness skin melanoma spheroid model with blood and lymphatic capillaries has been published in 2018 [40]. In this model fibroblasts were seeded onto peripheral paper anchors for sheet formation and stacked together with further separately prepared sheets consisting of human microvascular endothelial cells (HMVEC) and fibroblasts or melanoma spheroids and keratinocytes [40].

Furthermore, first approaches to develop immune enhanced 3D melanoma models have been started. For instance, one human 3D immune enhanced melanoma model with T-cells integrated in melanoma spheroids to study the young and the aged microenvironment in melanoma has been recently described [75]. Moreover, Votanopoulos et al. accomplished 3D lymph node/melanoma immune-enhanced organoids from the patient's own tumor, thereby reconstructing almost the exact in vivo situation, which may allow studies for personalized immunotherapy [74]. Importantly, while for healthy skin first human immunocompetent 3D full-thickness skin models with integrated Mutz-3, CD $34^{+}$or $\mathrm{CD} 4^{+} \mathrm{T}$-cells have been developed [79,80], no such model has been described for melanoma yet.

\section{Studying Invasion and Metastasis in human 3D full- thickness melanoma models}

From clinical and histopathological observations in patients, melanoma progression was divided in different phases. In an initial phase, aberrant hyperproliferation of melanocytes results in formation of a benign nevi, the earliest melanocytic lesion. Further aberrant growth and dysplasia leads to the Radial Growth Phase (RGP), which is defined by intraepidermal proliferation. This phase is followed by the Vertical Growth Phase (VGP) in which the cells start to grow vertically and invade into the dermis and subcutaneous tissue, finally leading to metastasis into distant organs, particularly into the brain $[81,82]$. Therefore, melanoma progressive events as invasion and metastasis are complex multistep events and cannot be investigated in $2 \mathrm{D}$ assays.

The first human 3D full-thickness melanoma invasion models have been developed 20 years ago. These models demonstrated that healthy melanocytes remain at the epidermal-dermal junction [66]. In addition, primary melanoma cells and melanoma cells from RGP could not invade into the dermis, but different cell lines from VGP as well as metastatic melanoma cell lines were able to cross the basal membrane and dissolute native ECM components (collagen IV and VII) [66$68,78]$. Importantly, metastatic melanoma cells were only able to cross the basal membrane in the presence of keratinocytes and fibroblasts $[66,83]$, underlining the influence of the cell-cell communication within the tumor stroma in melanoma invasion. Furthermore, invasion of melanoma cells through the basement membrane depends on the secretion of matrix metalloproteinase 9 by keratinocytes, which starts cleaving collagen type IV of the ECM after becoming activated by melanoma cells $[84,85]$. Notably, the invasive potential as well as the impact of fibroblasts and keratinocytes on melanoma invasion varies from cell line to cell line $[73,84]$.

After invading the dermis and in order to detach from the primary tumor and migrate to the surrounding tissue and distant sites, melanoma cells need to change their cytoskeletal organization and communicate with the surrounding cells and ECM [86,87]. In particular, a capillary network is necessary for circulating tumor cells to adhere to microvasculature and to move across the endothelial cell layer to distant organs $[88,89]$. With this knowledge, research regarding melanoma TME and vascularization has been forwarded. First human 3D full-thickness melanoma models for investigations of the pro-angiogenic and pro-lymphogenic impact of melanoma cells have been described just recently. The studies of Gibot et al. revealed that a metastatic melanoma cell line produces high levels of vascular endothelial growth factors (VEGF) resulting in pro-angiogenic effect on endothelial cells and leading to a more complex, branched and dense microvascular network in vitro. These results could be confirmed by Bourland et al., who developed the first human 3D full-thickness melanoma spheroid model including blood and lymphatic capillaries. The tumor spheroids secreted pro-lymphangiogenenic (VEGF-C) and pro-angiogenic (VEGF-A) factors as well as CC-chemokine ligand 21 (CCL21) and angiopoetin-2 (ANG-2) in reconstructed skin. Furthermore, as the tumor surrounding cells (fibroblasts and keratinocytes) in the reconstructed skin produced a similar amount of VEGF-C, indicating that angiogenesis and lymphangiogenesis may not only be modulated by tumor cells, but also by the surrounding cells [40]. 
Hölken JM (2020) Recent developments of 3D models of the tumor microenvironment for cutaneous melanoma: Bridging the gap between the bench and the bedside?

In conclusion, some cell lines are associated with RGP or advanced stages in VGP or metastasis [90], but invasion processes and progression from radial growth phase to vertical invasion and metastasis is still not fully understood and further investigations are required.

Notwithstanding, it is evident that the tumor microenvironment, cell-cell as well as cell-ECM communication are major contributors in melanoma invasion and metastasis. Thus, understanding and modeling the tumor microenvironment might be essential for therapeutic intervention in metastatic melanoma.

\section{Conclusion}

It becomes evident that monolayer cultures do not adequately recapitulate tumor biology for drug testing and that $3 \mathrm{D}$ models of the human skin are more appropriate models to study melanoma by considering the crucial role of its tumor microenvironment. Over the last 40 years 3D melanoma models have become increasingly sophisticated developing from mono- to co-culture and finally to vascularized and partially immunocompetent full-thickness skin models. Although various models are using reconstructed skin, most of them are based on exogenous biomaterials enriched with fibroblasts and keratinocytes. In contrast, recent $3 \mathrm{D}$ models based on extracellular matrix secreted by human fibroblasts, have the potential to model tumor invasion by adding human blood and lymphatic vascularization [40]. Such models may recreate a more complete microenvironment to study the effects of drug candidates and their potential to influence extravasation of tumor cells, a critical step in metastasis and a hallmark for melanoma.

However, with respect to the specific demands of innovative preclinical drug discovery, 3D model will have to manage the balancing act between robustness and miniaturization on the one hand and predictivity for the patient on the other hand. Especially, the amenability to robust medium or high throughput compound testing remains technologically challenging. Furthermore, it will be important to consider the use of primary tumor cells derived from patients instead of immortalized melanoma cell lines to characterize and identify drug candidates and select treatments for personalized medicine. In summary, despite of existing challenges, physiologically relevant in vitro 3D model might have the potential to partially replace animal testing according to the 3R-principle of Russell and Burch [91] by mimicking a human in vivo-like tumor microenvironment, potentially leading to improved clinical translation in oncology drug discovery in the future.

\section{Funding sources}

This work has not been funded.

\section{Conflict of interest}

There is no conflict of interest.

\section{References}

1. World Health Organization (2018) [May 7, 2020]. [Crossref]

2. Siegel RL, KD Miller, A. Jemal (2020) Cancer statistics. CA Cancer J Clin 70: 7-30. [Crossref]

3. Ferlay J, Shin HR, Bray F (2010) Estimates of worldwide burden of cancer in 2008: GLOBOCAN 2008. Int J Cancer 127: 2893-2917. [Crossref]

4. Sandru A, Voinea S, Panaitescu E (2014) Survival rates of patients with metastatic malignant melanoma. J Med Life 7: 572-576. [Crossref]

5. Tawbi HA, Boutros C, Kok D (2018) New Era in the Management of Melanoma Brain Metastases. Am Soc Clin Oncol Educ Book 38: 741-750. [Crossref]

6. Fox BD (2011) Epidemiology of metastatic brain tumors. Neurosurg Clin N Am 22: $1-6$, v. [Crossref]
7. Bafaloukos D, Gogas $\mathrm{H}$ (2004) The treatment of brain metastases in melanoma patients. Cancer Treat Rev 30: 515-520. [Crossref]

8. Fife KM, Colman MH (2004) Determinants of outcome in melanoma patients with cerebral metastases. J Clin Oncol 22: 1293-1300. [Crossref]

9. Raizer JJ, Hwu WJ, Panageas KS (2008) Brain and leptomeningeal metastases from cutaneous melanoma: survival outcomes based on clinical features. Neuro Oncol 10 . 199-207. [Crossref]

10. Sampson JH (1998) Demographics, prognosis, and therapy in 702 patients with brain metastases from malignant melanoma. J Neurosurg 88: 11-20. [Crossref]

11. Luke JJ, Flaherty KT, Ribas A (2017) Targeted agents and immunotherapies: optimizing outcomes in melanoma. Nat Rev Clin Oncol 14: 463-482. [Crossref]

12. Goyal S, Silk AW (2015) Clinical management of multiple melanoma brain metastases: A systematic review. JAMA Oncol 1: 668-676. [Crossref]

13. Hodi FS, O'Day SJ (2010) Improved survival with ipilimumab in patients with metastatic melanoma. N Engl J Med 363: 711-723. [Crossref]

14. Robert C (2011) Ipilimumab plus dacarbazine for previously untreated metastatic melanoma. $N$ Engl J Med 364: 2517-2526. [Crossref]

15. Robert C, Schachter J (2015) Pembrolizumab versus Ipilimumab in Advanced Melanoma. N Engl J Med 372: 2521-2532. [Crossref]

16. Robert C (2015) Nivolumab in previously untreated melanoma without BRAF mutation. N Engl J Med 372: 320-330. [Crossref]

17. Wolchok JD (2017) Overall survival with combined nivolumab and ipilimumab in advanced melanoma. $N$ Engl J Med 377: 1345-1356. [Crossref]

18. Chapman PB, Hauschild A (2011) Improved survival with vemurafenib in melanoma with BRAF V600E mutation. $N$ Engl J Med 364: 2507-2516. [Crossref]

19. Larkin, J, Ascierto PA, Dreno B (2014) Combined vemurafenib and cobimetinib in BRAF-mutated melanoma. $N$ Engl J Med 371: 1867-1876. [Crossref]

20. Long GV, Flaherty KT, Stroyakovskiy D (2017) Dabrafenib plus trametinib versus dabrafenib monotherapy in patients with metastatic BRAF V600E/K-mutan melanoma: long-term survival and safety analysis of a phase 3 study. Ann Oncol 28 : 1631-1639. [Crossref]

21. Dummer R, Ascierto PA, Gogas HJ (2018) Overall survival in patients with BRAFmutant melanoma receiving encorafenib plus binimetinib versus vemurafenib or encorafenib (COLUMBUS): a multicentre, open-label, randomised, phase 3 trial Lancet Oncol 19: 1315-1327. [Crossref]

22. Arrowsmith J (2011) Trial watch: phase III and submission failures: 2007-2010. Nat Rev Drug Discov 10: 87. [Crossref]

23. Hay M, Thomas DW JL, Craighead (2014) Clinical development success rates for investigational drugs. Nat Biotechnol 32: 40-51. [Crossref]

24. Nair RR, Padhee S (2017) Three- and Four-Dimensional Spheroid and FiSS Tumoroid Cultures: platforms for drug discovery and development and translational research. Crit Rev Ther Drug Carrier Syst 34: 185-208. [Crossref]

25. Xie B, Teusch N, Mrsny R (2020) Comparison of two-and three-dimensional cance models for assessing potential cancer therapeutics, in Biomaterials for Cancer Therapeutics. Elsevier 399-422. [Crossref]

26. Dunki-Jacobs EM, Callender GG, McMasters KM (2013) Current management of melanoma. Curr Probl Surg 50: 351-382. [Crossref]

27. Bald T, Quast T, Landsberg J (2014) Ultraviolet-radiation-induced inflammation promotes angiotropism and metastasis in melanoma. Nature 507: 109-113. [Crossref]

28. Dvorankova B, Szabo P, Kodet O (2017) Intercellular crosstalk in human malignant melanoma. Protoplasma 254: 1143-1150. [Crossref]

29. Fidler IJ (2003) The pathogenesis of cancer metastasis: the 'seed and soil' hypothesis revisited. Nat Rev Cancer 3: 453-458. [Crossref]

30. Hanahan D, Coussens LM (2012) Accessories to the crime: functions of cells recruited to the tumor microenvironment. Cancer Cell 21: 309-322. [Crossref]

31. Joyce JA (2005) Therapeutic targeting of the tumor microenvironment. Cancer Cell 7 513-520. [Crossref]

32. Kolar M, Szabo P, Dvorankova B (2012) Upregulation of IL-6, IL-8 and CXCL1 production in dermal fibroblasts by normal/malignant epithelial cells in vitro: Immunohistochemical and transcriptomic analyses. Biol Cell 104: 738-751. [Crossref] 
Hölken JM (2020) Recent developments of 3D models of the tumor microenvironment for cutaneous melanoma: Bridging the gap between the bench and the bedside?

33. Kučera J, Dvořánková B (2015) Fibroblasts isolated from the malignant melanoma influence phenotype of normal human keratinocytes. J Appl Biomed 13: 195-198. [Crossref]

34. Jobe NP, Rosel D, Dvorankova B (2016) Simultaneous blocking of IL-6 and IL-8 is sufficient to fully inhibit CAF-induced human melanoma cell invasiveness. Histochem Cell Biol 146: 205-217. [Crossref]

35. Herraiz C, Jiménez-Cervantes C, Sánchez-Laorden B (2018) Functional interplay between secreted ligands and receptors in melanoma. Semin Cell Dev Biol 78: 73-84. [Crossref]

36. Alegre E, Sammamed M, Fernández-Landázuri S (2015) Circulating biomarkers in malignant melanoma, in Adva Clinical Chem. Elsevier 47-89. [Crossref]

37. Filitis DC, Rauh J, Mahalingam M (2015) The HGF-cMET signaling pathway in conferring stromal-induced BRAF-inhibitor resistance in melanoma. Melanoma Res 25: 470-478. [Crossref]

38. Weidle UH, Birzele F, Kollmorgen G (2017) The multiple roles of exosomes in metastasis. Cancer Genomics Proteomics 14: 1-15. [Crossref]

39. Romano G, Kwong LN (2017) miRNAs, Melanoma and Microenvironment: An Intricate Network. Int J Mol Sci 18: 2354. [Crossref]

40. Bourland J, Fradette J (2018) Tissue-engineered 3D melanoma model with blood and lymphatic capillaries for drug development. Sci Rep 8: 13191. [Crossref]

41. Gasser S (2017) The role of the tumour microenvironment in immunotherapy. Endocr Relat Cancer 24: T283-T295. [Crossref]

42. Bhatia S, Oweida A (2019) Inhibition of EphB4-Ephrin-B2 Signaling reprograms the tumor immune microenvironment in head and neck cancers. Cancer Res 79: 27222735. [Crossref]

43. Fujimura T, Kakizaki A (2016) Tumor-associated macrophages in skin: how to treat their heterogeneity and plasticity. J Dermatol Sci 83: 167-173. [Crossref]

44. Voiculescu VM, Lisievici CV, Lupu M (2019) Mediators of inflammation in topical therapy of skin cancers. Mediators Inflamm 2019: 8369690. [Crossref]

45. Pieniazek M, Matkowski R, Donizy P (2018) Macrophages in skin melanoma-the key element in melanomagenesis. Oncol Lett 15: 5399-5404. [Crossref]

46. Tarazona R, Duran E, Solana R (2015) Natural killer cell recognition of Melanoma: New clues for a more effective immunotherapy. Front Immunol 6: 649. [Crossref]

47. Saadeh D, Kurban M, Abbas O (2016) Plasmacytoid dendritic cell role in cutaneous malignancies. J Dermatol Sci 83: 3-9. [Crossref]

48. Kapalczynska M, Kolenda T, Przybyla W (2018) 2D and 3D cell cultures - a comparison of different types of cancer cell cultures. Arch Med Sci 14: 910-919. [Crossref]

49. Hoarau-Véchot J, Rafii A, Touboul C (2018) Halfway between 2D and animal models are $3 \mathrm{D}$ cultures the ideal tool to study cancer-microenvironment interactions? Int $J$ of Mol Sci 19: 181. [Crossref]

50. Edmondson R, Broglie JJ, Adcock AF (2014) Three-dimensional cell culture systems and their applications in drug discovery and cell-based biosensors. Assay Drug Dev Technol 12: 207-218. [Crossref]

51. Jensen C, Teng Y (2020) Is it time to start transitioning from 2D to 3D cell culture? Front Mol Biosci 7: 33. [Crossref]

52. Herlyn M (1987) Expression of melanoma-associated antigens in rapidly dividing human melanocytes in culture. Cancer Res 47: 3057-3061. [Crossref]

53. Kamb A, Shattuck-Eidens D (1994) Analysis of the p16 gene (CDKN2) as a candidate for the chromosome 9p melanoma susceptibility locus. Nat Genet 8: 23-26. [Crossref]

54. Guldberg P, Kirkin AF, Gronbaek K (1997) Complete scanning of the CDK4 gene by denaturing gradient gel electrophoresis: a novel missense mutation but low overall frequency of mutations in sporadic metastatic malignant melanoma. Int J Cancer 72: 780-783. [Crossref]

55. Rodríguez NC, Lineros J, Rodríguez CS (2019) Establishment of Two Dimensional (2D) and Three-Dimensional (3D) melanoma primary cultures as a tool for In Vitro drug resistance studies, in immune checkpoint blockade. Springer 119-131. [Crossref]

56. Vorsmann H, Groeber F, Walles H (2013) Development of a human three-dimensiona organotypic skin-melanoma spheroid model for In Vitro drug testing. Cell Death Dis 4: e719. [Crossref]

57. Mak IW (2014) Lost in translation: animal models and clinical trials in cancer treatment. Am J Transl Res 6: 114-118. [Crossref]
58. Li L, Fukunaga-Kalabis M (2011) The three-dimensional human skin reconstruct model: a tool to study normal skin and melanoma progression. J Vis Exp 3. [Crossref]

59. Smalley KS, Lioni M (2008) In vitro three-dimensional tumor microenvironment models for anticancer drug discovery. Expert Opin Drug Discov 3: 1-10. [Crossref]

60. Romsdahl MM (1967) Etablishment and biologic properties of human malignant melanoma cell lines grown In Vitro. Surg Forum 18: 78. [Crossref]

61. Folkman J, Hochberg M (1973) Self-regulation of growth in three dimensions. $J$ Exp Med 138: 745-753. [Crossref]

62. Giard DJ, Aaronson SA, Todaro GJ (1973) In vitro cultivation of human tumors: establishment of cell lines derived from a series of solid tumors. J Natl Cancer Inst 51 1417-1423. [Crossref]

63. Rheinwald JG, Green H (1975) Serial cultivation of strains of human epidermal keratinocytes: the formation of keratinizing colonies from single cells. Cell 6: 331-343. [Crossref]

64. Bell E, Ehrlich HP, Buttle DJ (1981) Living tissue formed in vitro and accepted as skinequivalent tissue of full thickness. Science 211: 1052-1054. [Crossref]

65. Wibe E, Berg JP, Tveit KM (1984) Multicellular spheroids grown directly from human tumour material. Int J Cancer 34: 21-26. [Crossref]

66. Eves P, Layton C (2000) Characterization of an in vitro model of human melanoma invasion based on reconstructed human skin. Br J Dermatol 142: 210-222. [Crossref]

67. Dekker SK (2000) Skin equivalent: an attractive model to evaluate early melanoma metastasis. Melanoma Res 10: 127-140. [Crossref]

68. Meier F, Nesbit M, Hsu MY (2000) Human melanoma progression in skin reconstructs : biological significance of bFGF. Am J Pathol 156: 193-200. [Crossref]

69. Fang D, Nguyen TK, Leishear K (2005) A tumorigenic subpopulation with stem cell properties in melanomas. Cancer Res 65: 9328-9337. [Crossref]

70. Gibot L, Galbraith T, Huot J (2013) Development of a tridimensional microvascularized human skin substitute to study melanoma biology. Clin Exp Metastasis 30: 83-90. [Crossref]

71. Hill DS, Robinson ND, Caley MP (2015) A novel fully humanized 3d skin equivalent to model early melanoma invasion. Mol Cancer Ther 14: 2665-2673. [Crossref]

72. de Godoy Marques CM, MacNeil S (2016) Use of a tissue engineered human skin model to investigate the effects of wounding and of an anti-inflammatory on melanoma cell invasion. PloS one 11 [Crossref]

73. Haridas P, McGovern JA, McElwain SDL (2017) Quantitative comparison of the spreading and invasion of radial growth phase and metastatic melanoma cells in a threedimensional human skin equivalent model. PeerJ 5: e3754. [Crossref]

74. Votanopoulos KI, Forsythe S, Sivakumar H (2019) Model of Patient-Specific ImmuneEnhanced organoids for immunotherapy screening: Feasibility study. Ann Surg Oncol 27: 1956-1967. [Crossref]

75. Kaur A, Ecker BL, Douglass SM (2019) Remodeling of the collagen matrix in aging skin promotes melanoma metastasis and affects immune cell motility. Cancer Discov 9: 64-81. [Crossref]

76. Inch WR (1970) Growth of nodular carcinomas in rodents compared with multi-cell spheroids in tissue culture. Growth 34: 271-282. [Crossref]

77. Sutherland RM (1971) Growth of multicell spheroids in tissue culture as a model of nodular carcinomas. J Natl Cancer Inst 46: 113-120. [Crossref]

78. Bechetoille N, Haftek M (2000) Penetration of human metastatic melanoma cells through an authentic dermal-epidermal junction is associated with dissolution of native collagen types IV and VII. Melanoma Res 10: 427-434. [Crossref]

79. Kosten IJ (2015) MUTZ-3 derived Langerhans cells in human skin equivalents show differential migration and phenotypic plasticity after allergen or irritant exposure. Toxicol Appl Pharmacol 287: 35-42. [Crossref]

80. Rodrigues Neves C (2018) Progress on reconstructed human skin models for allergy research and identifying contact sensitizers. Curr Top Microbiol Immunol 23. [Crossref]

81. Clark WH Jr (1984) A study of tumor progression: the precursor lesions of superficial spreading and nodular melanoma. Hum Pathol 15: 1147-1165. [Crossref]

82. Elder DE (2016) Melanoma progression. Pathology 48: 147-154. [Crossref]

83. Neil SM, Eves P, Richardson B (2000) Oestrogenic steroids and melanoma cell interaction with adjacent skin cells influence invasion of melanoma cells in vitro. Pigment Cell Res 8: 68-72. [Crossref] 
Hölken JM (2020) Recent developments of 3D models of the tumor microenvironment for cutaneous melanoma: Bridging the gap between the bench and the bedside?

84. Eves P, Katerinaki E, Simpson C (2003) Melanoma invasion in reconstructed human skin is influenced by skin cells--investigation of the role of proteolytic enzymes. Clin Exp Metastasis 20: 685-700. [Crossref]

85. Van Kilsdonk JW, Bergers M, Van Kempen LC (2010) Keratinocytes drive melanoma invasion in a reconstructed skin model. Melanoma Res 20: 372-380. [Crossref]

86. Quail DF, Joyce JA (2013) Microenvironmental regulation of tumor progression and metastasis. Nat Med 19: 1423-1437. [Crossref]

87. Aladowicz E (2013) Molecular networks in melanoma invasion and metastasis. Future Oncol 9: 713-726. [Crossref]
88. Fidler IJ (2015) The challenge of targeting metastasis. Cancer Metastasis Rev 34: 635641. [Crossref]

89. Alitalo A, Detmar M (2012) Interaction of tumor cells and lymphatic vessels in cancer progression. Oncogene 31: 4499-4508. [Crossref]

90. Hsu MY, Elder DE, Herlyn M (1999) Melanoma: The Wistar Melanoma (WM) cel lines, in human cell culture: Cancer cell lines part 1. J.R.W. Masters and B. Palsson, Editors, Springer Netherlands: Dordrecht: 259-274. [Crossref]

91. Flecknell P (2002) Replacement, reduction and refinement. ALTEX 19: 73-78. [Crossref]

Copyright: (C2020 Hölken JM. This is an open-access article distributed under the terms of the Creative Commons Attribution License, which permits unrestricted use, distribution, and reproduction in any medium, provided the original author and source are credited. 